\title{
Organic Waste Management in Sukoanyar, Mojo, Kediri
}

\author{
Fatkur Rhohman, Moh. Muslimin Ilham, AM. Mufarrih, Nuryosuwito \\ \{fr_kediri@yahoo.com,im.muslimin@yahoo.co.id, emailpenulisketiga@ mail.com, \\ suwito.unp@gmail.com\} \\ Mechanical Departement, Nusantara PGRI Kediri University, Kediri, Indonesia
}

\begin{abstract}
Waste management is a problem has not been done properly and perfectly. Many factors that take effect of success in implementing waste management, especially household waste. the problem of waste, especially house hold waste will be increasing until out of control if it is not immediately to get the solve. All of them, must be starting from it selt. So the purpose of this event is to empower the awareness of people, adult and youth to process organic waste that produced in their environment. In this activity, people espesially women adult and youths are taught to process organic waste. It can be used as compost. The tools provided are 2 (two) types, composter and biopori maker. With composter, people are given learning about processing organic waste into become a compost that can be save for later use, which does not require land. Then biopori maker is used to make compost with used natural proces for people who have land.
\end{abstract}

Keywords: Organic Waste, Compost, Composter, Biopori maker.

\section{Introduction}

Waste management is a problem has not been done properly and perfectly. Even longer, waste production is increasing. Every Day, Waste Production in indonesia are 65 Million Tons [1]. Depend from the composition of the waste, organic waste is the highest waste generated [2]. Organic waste for every town can reach $70 \%$ of total waste, and about $28 \%$ is non-organic waste which is an object of potential income for picker activity, starting from garbage sources (from houses) to landfill. The rest (around 2\%) is classified as B3 which needs to be managed separately [3]. Organic waste is a type of waste that is easily decomposed and has the potential to pollute the environment and public health. Management and processing is absolutely necessary so that the environment becomes clean and phealth [4]. The people as a waste producer has the most important role to solve the garbage problem. there needs active participation in managing the waste and it must be started from households by sorting organic waste, non-organic waste and B3 waste, so that only the rest will be transported to landfill [5]. 


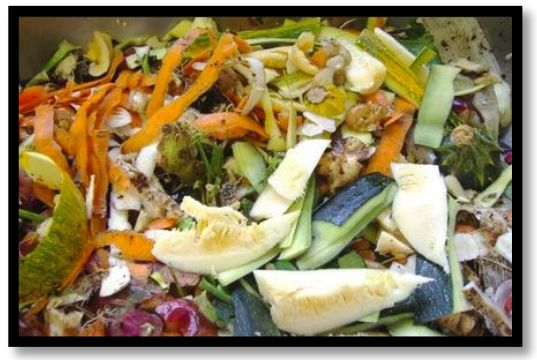

Fig. 1. Houshold Waste

In the dictionary of environment, waste is a material that has no value or is not valuable for ordinary or primary purposes in fabrication or use of damaged or defective goods in manufacturing or excessive or rejected material or waste. According to Ecolink, waste is a material that is throw away or discarded from the source of human activities and natural processes that do not have economic value. Whereas according to Dr. Tandjung, waste is something that is no longer useful, discarded by its owner or original user [6]. Problems from waste if not handled properly are [7]:

a. Decreasing aesthetic value of the environment, environment becomes dirty

b. Air pollution by gases that produce from waste, such as methane gas or $\mathrm{CO} 2$ that resulting from combustion waste

c. Soil pollution from hazardous and toxic materials in waste

d. Water Pollution from hazardous and toxic materials that seeps into ground water or surface water around the waste

e. The complexity of the waste management system because involves many people and many costs that encourage corruption, collusion and nepotism

f. Overloading the people to pay for cost waste management regularly

g. disruption of public health with decreasing quality of environmental sanitation

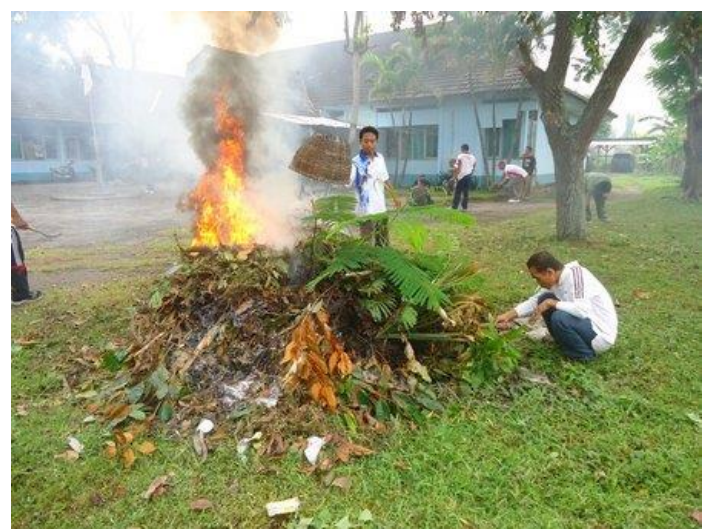

Fig. 2. People burn leafes waste

so, there needs to be a serious effort from all the people to solve the problem of the garbage, especially household organic waste. To solve the problem, the government through KLH developed a new idea, namely $4 \mathrm{R}$, which was a development of $3 \mathrm{R}$. The $4 \mathrm{R}$ program includes [7]: 


\section{a. Reduce (save usage)}

Step one that can be used in this reduce activity is using more less of packaging. It can do by buying fresh food and not packaged in plastic. Replacing shopping bags from plastic with recycled bags, paper, or other materials that are environmentally friendly

b. Reuse (Use Again)

several efforts that can be used in this activity are: extending the service life and developing other benefits.

\section{c. Recycling}

That can be done from recycling are: make another product from waste plastic or paper, make an organic waste into compost, and others. there are 3 ways to recycle organic waste to be compost, including: Composting with EM4 activators, composting in a simple way in the ground, and composting using a composter.

d. Replant (Replanting)

Replant is an effort to make the empty land become green.

Therefore, the purpose of this activity is to support the awareness of peoples especially housewives and youth to process organic waste that produced from their environment. Processing in this case refer to 2 activities, are sorting organic and inorganic waste, and processing organic waste [8].

\section{Methods}

The implementation of this activity has 3 ways, are:

\section{a. Counseling about garbage}

Counseling aims to give knowledge about waste to the people especially youth and housewive on the Posyandu society. This counseling continuously give because from the results of the research, counseling can have a real influence on the respondents to sort out the waste after being given in the same time at the location [9].

\section{b. Training how to process organic waste become compost}

After counseling was conducted, training was also held on sorting organic and anorganic waste. Anorganic waste can be sold to scrubbers, while organic waste is used for compost. This is based on the fact from the survey, $71 \%$ of the housewife, stated that economic factors become one of the determinants in determining anythink [9]. So in other words they will process waste that can be resold. The method of making compost that we give to the people use 4 ways, among other: using a composter that will process organic waste with an anaerobic system, using a composter that will process organic waste with an aerobic system, composting organic waste by utilizing biopori which can apply in the ground, and use direct organic waste for mixing media in polybags. 
c. Mentoring environtment participans to promoting 4R (Reduce, Reuse, Recycle, and Replant)

$4 \mathrm{R}$ method that applied to organic waste is recycling organic waste. Mentoring aims to see the progress of the activities that have been given. In the other hand, it's also used to see opportunities that can be used to solve garbage problems even better, such as the procurement of enumerators to support the program of making compost so that it can be an alternative business in the village.

\section{Results and Discussion}

In implementing this dedication activity, the results are given:

\section{a. Counseling about waste}

Counseling was given to explanation of waste, the effects of bad management of waste, and how to manage organic and anorganic waste. Counseling is carried out for people especially housewive and people who participate in the posyandu activities. So the counseling activities can be carried out continuously through the activities of meeting in the group discussion in the village and posyandu activities

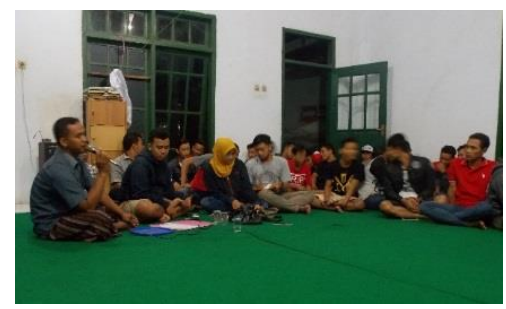

Fig. 3. Counseling with young people

The managing of the waste is become effetive if the management doing early. Start from home, start from everyone. If every people has do it, the management of waste can optimized in the concerned groups. With the group, goverment, private, and university are easy to give incentive supervising [10].

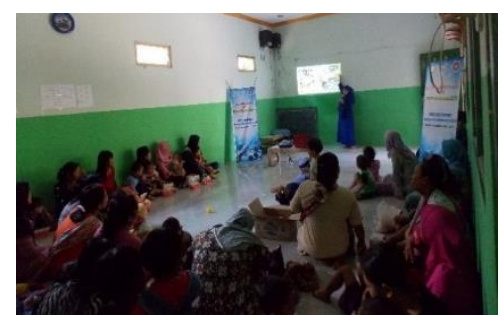

Fig. 4. Counseling with housewif 
b. Training to process organic waste to made into compost, both with a composter and with a ground digger (biopori tool)

For processing organic waste, people is given three (3) alternative processing methods, first composting, second methanetion, and third for animal feed. For composting, many variations of this method have been exemplified to doing by people such as aerobic methods, anaerobic methods, worm methods (compost production with the help of worms to accelerate the process of bio-degradation) and conventional methods[8].

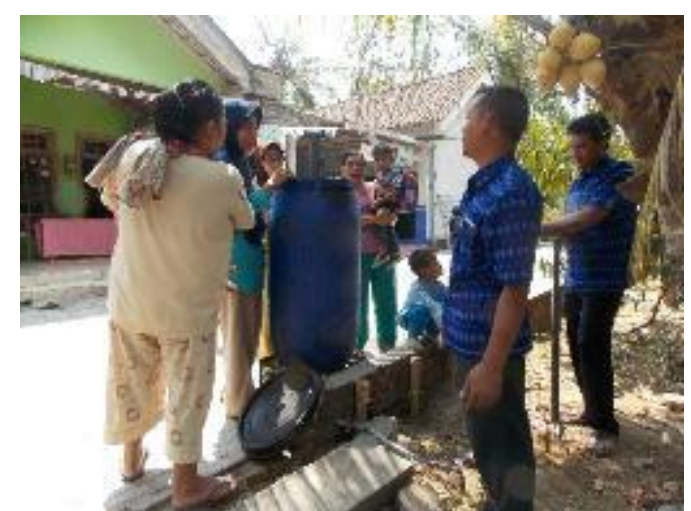

Fig. 5. Counseling how to make compost with digester

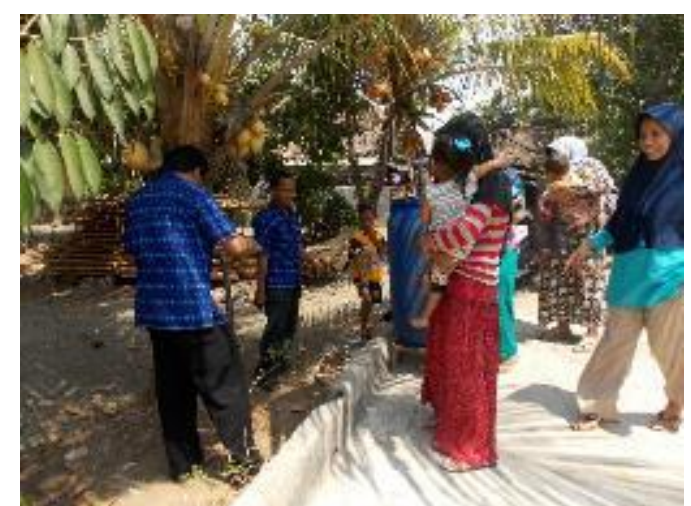

Fig. 6. Counseling how to make compost with ground digger (Biopori tool)

\section{c. Guidance of environment participans to do assisting the implementation of waste management by people in the Sukoanyar village.}

This assistance also has to see the level success of waste management activity that has be done. Of the three methods have written above, all of them can be do well. But, many people using conventional methode to make organic waste become compost. They use digger tool to dig the ground, then the organic waste filling into the hole in the ground. Ans the last, they close the hole what has fill with the organic waste with soil. The reason is that it is easy to make biopores, it does not take long time to process waste, and can be directly applied to fertilize plants. 


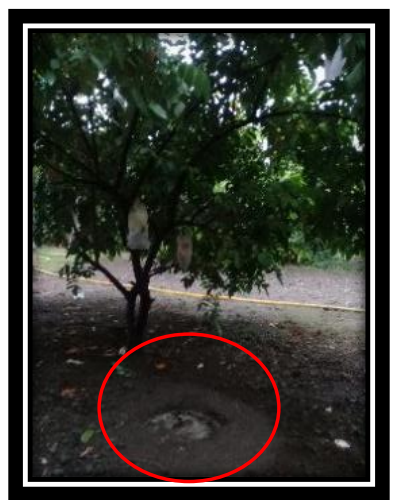

Fig. 7. Biopori which has full with leave waste close by soil

People who have a land with plant, make a hole in the ground to make a leave waste become compost. The leave waste fill to the hole. If the leave waste is full, then closed with the soil.

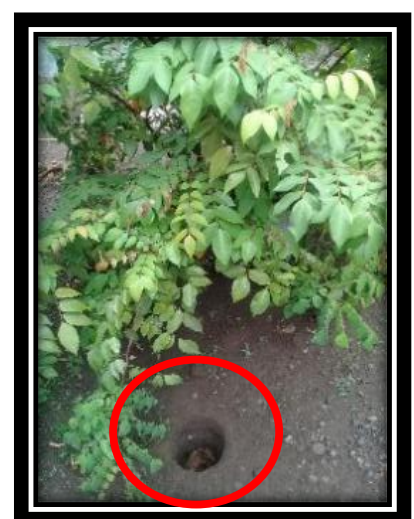

Fig. 8. hole in the ground that fill with the organic waste especially leave waste

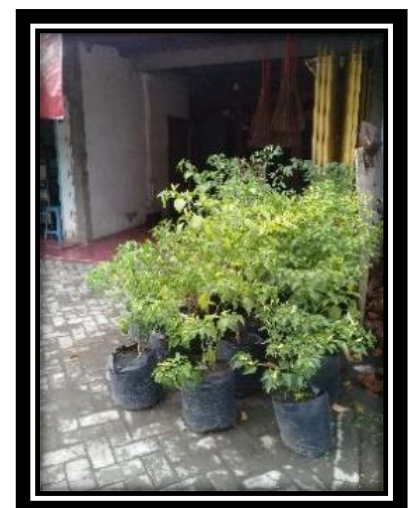

Fig. 9. People use the compost to plant vegetable in the polybag

People who have not a land to planting a plant, use the polybag to contain a plant. Compost used to replace soil as a plant medium in the polubag. Many vagetable can planting in the 
polybag. But, any people trying to use leave waste what have not been become a compost. Thay use leave waste that mix with soil and give some worm. All of them is filling in the polybag. We dont know how effective of that way. So we must lok the effectivity of that way, and we must do the observation to get a valid information.

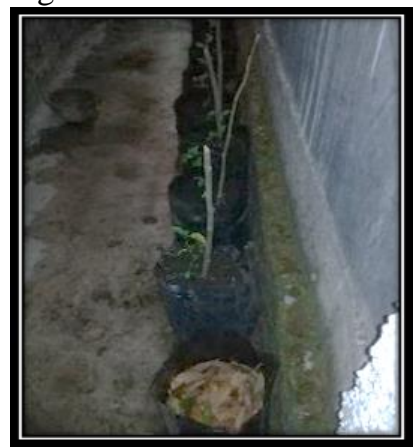

Fig. 10. Mixing of leave waste, soil and warm that fill into the polybag to plant a vegetables

Handling of organic waste is the beginning habituation of people to able appling the ecoefficient concept, that mentioned in the framework of the Indonesia-Germany environmental program. In this concept, eco means economic efficiency and ecologic efficiency. Efficiency means using economic resources as effectively as possible to sufficien human needs and desires, so that no resources are wasted. Waste recycling efforts are one of the key factors in the concept of eco-efficiency (EE). The EE concept was first introduced in 1992 by the World Business Council for Sutainable Development (WBCSD) in the publication of Changing Course. WBCSD has identified seven key factors in eco-efficiency, there are: reducing the amount of material use, reducing the amount of energy use, reducing pollution, increasing recycling of materials, maximizing the use of natural resources that can be renewed, extending product life, and increasing service intensity [11].

\section{Conclussion}

Waste management needs to be done starting from the household environment, because the biggest waste comes from kitchen waste. So that efforts to handle waste will be better if given directly to housewives. Youth also needs to be trained so that they are accustomed to not littering and helping to make waste management successful starting from the household scale.

\section{Acknowledgements}

Proin pharetra nonummy pede. Mauris et orci. Aenean nec lorem. In porttitor. Donec laoreet nonummy augue. Suspendisse dui purus, scelerisque at, vulputate vitae, pretium mattis, nunc. Mauris eget neque at sem venenatis eleifend. Ut nonummy.

a. Dedication team in mechanical engineering study program, Universitas Nusantara PGRI Kediri

b. Universitas Nusantara PGRI Kediri

c. The Sukoanyar Village Government has given permission to do dedication activity 


\section{References}

[1] M. Aris and M. Sudiaman, "Setiap Hari Indonesia Produksi Sampah 65 Juta Ton," Republika.co.id, 2017. [Online]. Available: https://nasional.republika.co.id/berita/nasional/daerah/17/03/15/omv2sg319-setiap-hariindonesia-produksi-sampah-65-juta-ton. [Accessed: 24-Dec-2018].

[2] A. A. Kadir and S. S. S. Z. Abidin, "Solid Waste Composition and Quantification at Solid Waste Composition and Quantification at Taman Melewar, Parit Raja , Batu Pahat," in IOP Conference Series: Materials Science and Engineering, 2016, p. 136012047.

[3] E. Damanhuri and T. Padmi, "Pengelolaan Sampah," in Republik Indonesia, Bandung: Program Studi Teknik LIngkungan, Institut Teknologi Bandung, 2008, pp. 1-46.

[4] S. Wahyono, "Pengolahan Sampah Organik dan Aspek Sanitasi," J. Teknol. Lingkung., vol. 2, no. 2 , pp. 113-118, 2001.

[5] S. Subekti, "Pengelolaan Sampah Rumah Tangga 3R Berbasis Masyarakat," in Prosiding Seminar Nasional Sains Dan Teknologi Fakultas Teknik Universitas Wahid Hasyim Semarang, 2010, pp. 24-30.

[6] VEDC Malang, Sampah dan Pengelolaannya. Malang: Indah Offset, 1998.

[7] KLH, "Buku Panduan Mengelola Sampah Rumah Tangga Dengan Prinsip 4R (Reduce, Reuse, Recycle, Replant).” Kementrian Lingkungan Hidup RI, Pakanbaru, Riau, 2007.

[8] KNLH, Panduan Praktis Pemilahan Sampah. Jakarta: Kementrian Negara Lingkungan Hidup RI, 2008.

[9] A. S. Yudistirani, L. Syaufina, and S. Mulatsih, "Desain Sistem Pengelolaan Sampah melalui Pemilahan Sampah Organik dan Anorganik Berdasarkan Persepsi Ibu-ibu Rumah Tangga," Konversi, vol. 4, no. 2, pp. 29-42, 2015.

[10] B. H. Widayanti, F. P. Hirsan, and A. Kurniawan, "Effectiveness of waste management in Mataram City," in IOP Conference Series: Earth and Environmental Science, 2017, p. 70 012004 .

[11] R. Riswan, H. R. Sunoko, and A. Hadiyarto, "Pengelolaan Sampah Rumah Tangga Di Kecamatan Daha Selatan,” J. Ilmu Lingkung., vol. 9, no. 1, pp. 31-39, 2011. 